\title{
Study on the Learning Model of College Students Based on Mobile Internet
}

\author{
Yanxin Xie \\ Jilin Agricultural Science and Technology College, Jilin, China \\ 592228272@qq.coml
}

Keywords: IT professionals; Team-Based Learning; Entrepreneurial ability; Building knowledge

\begin{abstract}
With the development of computer talents in the increasingly fierce market competition, new industrial core competitiveness and modern service industry rising in recent years, high-tech modern agriculture base constantly emerging, therefore IT talents who have rich practical experience [1], occupation ability and Entrepreneurial ability are needed. This will give us a higher IT personnel $t$ raining requirements and brings new challenges. The main purpose of this article is to explore common IT professional teacher can build a strong team of teachers and train better multi-faceted type talents through Information consultation and participating enterprise technology research according Team-Based Learning mode.
\end{abstract}

\section{Foreword}

Chinese Agricultural Academy training model continues to expand, Talent can be divided into general research, complex, application-oriented categories. They each have different levels. Applied research talent's main task is to explore and discover the law of Agricultural Science and Technology. Complex talent's main task is to use a known law to do application, Technology research and development theory, Planning decision making, leadership "transformation of agriculture." ${ }^{[2]}$.Applied Talents' main task is to design, plan implementation in the agricultural production or social service line and have the ability of Application Research.

In the information society of taking the computer technology as the representative, Computer technology has been integrated into various fields including agriculture and it is playing an irreplaceable role. Regardless of the above three types of agricultural talents how to play the role in the industry, Computer technology has become their indispensable skills. In this sense, the construction of program group should help to clear the relationship among professional knowledge, professional skills, curriculum and textbooks. It's helpful for students to learn, understand and master.

\section{Some Problems of IT Talents Training Exist in Agricultural University}

At present, we still have the problem of training model: firstly, there is a big gap between training college students' learning and the employment needs, so students can't adapt to society after their graduation. Secondly, information and computer technology in the industry should be updated every six months. As we known, the update rate is so fast. Personnel training programs in the education sector cannot be adjusted at any time like social training institutions. There are several issues in their learning:

(1) To help IT professionals in colleges and universities clear educational philosophy and school orientation;

(2) To help IT professionals with restructuring, and reduce the problem of unemployment of university graduates;

(3) To promote professional development, curriculum reform, teaching staff, and personnel training program design;

(4) To promote employment training program optimization in colleges and universities;

(5) To help college students to promote innovative projects. 


\section{Targeting of Undergraduate Level Applied Talents}

Application-oriented talents should be trained in the professional. They need to adapt to economic and social development,face to line of information industry; they should master the basic theory of solid IT related disciplines,basic knowledge and basic skills; They should have the abilities in application software development and maintenance, information technology integration and data and network management[3].

Graduates can work in the information industry related enterprises and institutions engaged in software development and maintenance, systems integration, data and network management. They have the ability to unity and cooperation. They have a solid basic theory, basic knowledge and basic skills about Mathematics, computer science and technology disciplines and related disciplines. They master application software development and maintenance, information technology integration, data and network management, identification and evaluation techniques timeliness to assess their applicability and implementation of the organization according to user needs. They should be familiar with the information industry policies and regulations. They have software engineer professional capacity. They have the ability of strong communication and expression and they can use modern information technology to obtain relevant information. They have the ability of preliminary research and practical work.

\section{Teaching Model Innovation}

Identify Research Objectives. Team-Based Learning is presented by the University of Oklahoma as a teaching model is designed to strengthen students' overall ability to practice and teamwork, which comes from the teaching philosophy of education innovators Dr. Michae Lsen LK 's design. He advocated a new way to re-organize the classroom teaching [4]. That is to organize a team of students to face challenging and complex learning tasks. Research goal is to be able to train IT professionals who can service in contemporary and have innovative ability, entrepreneurial ability, professional skills and rich experience.

As a general category of applied agricultural colleges, the build of professional training programs should epitomize positioning of College Applied Talents Specification and fully reflect the needs of society and meet industry requirements for quality of talent. It reflects a full upgrade converted by a specialist undergraduate connotation in terms of strengthening students' comprehensive quality training. The study is beginning from the transformation of educational concepts, by positioning the application-oriented. We research comprehensive and systematically on these aspects including professional colleges of applied agricultural structure, characteristics, teaching, training mode, teaching approaches and assessment measures from the theoretical and practical aspects. This study is mainly to practice research in Jilin College of Agricultural Science and Technology and supplemented with research related to similar institutions. Jilin College of Agricultural Science and Technology was upgraded to agricultural colleges in 2004. School personnel training objectives positioned in training on application-oriented talents, and mission positioned for regional economic development services and for "agricultural services"[5].

The Main Content of the Study. (1)Social research and analysis. Analyzed according to talent needed model in today's society. On the status of the current IT industry research how to develop common institutions of professional training programs. (2) Personnel training objectives and planning. Combined with the requirements of today's IT industry development, we analyze modern IT industry personnel training objectives and requirements. (3)Status of IT professional service system. "Regional Service System" based IT perspective we analyze the problems about IT personnel training professional. Development, curriculum, practical aspects, scientific research, innovative projects, and achievements. (4)Construction of IT professional service system According to the service system colleges should carry out scientific research activities. They can participate in industry enterprise project development, and participate in the network management, modern service industry, and 
modern logistics informationization. They can build output - learning - research system integration services.

Introduction of TBL Mode. In Team-Based Learning mode, the students formed a team of 3-5 people with an academic tutor starting next semester freshman year. Team combination can only be replaced once in sophomore. Students need to complete the teaching practice,Teacher Project,and Students' Innovation Project in the form of the team. Outstanding team can apply to participate in various competitions such as ACM and the Electronic Design Competition. In the eighth semester, students go to school in the training base for short-term training (Admitted to graduate school students cannot participate in training).

\section{Exploration and Practice of Applied Talents Teaching Model Innovation based on TBL}

Establish a Rational Curriculum. Improve the Content of Theoretical and Experimental Teaching. Curriculum system is the link between clearing the curriculum system expertise and clearing relationship between classes each trunk. It will increase the elective course, and strengthen the training of IT personnel skills in certain direction ${ }^{[6]}$.

According to the positioning of school-based curriculum,curriculum unit in-depth studies teaching in the construction period. They planned teaching system from 2008 to 2011 year. They redesigned the curriculum module content,sequence and added experimental teaching. They scaled experimental teaching. It more highlights the philosophy and goals of training. It achieved a standardized lesson plans and handouts. It standardized curriculum focus and difficulty. Guiding ideology of the experimental teaching system is innovative. It established the guiding ideology and mode of the experimental teaching based on task driven and developed supporting experimental guidance note based on this system.

Establishes a Framework for Close Output - Learning - Research Cooperation System Type. The framework is divided into three levels, the hardware environment, software environment, knowledge service system (system hierarchy diagram refer with: Fig. 1).Students are allowed to participate in the teacher's scientific research. The experiment lasted three years proved these students can post directly after graduation.

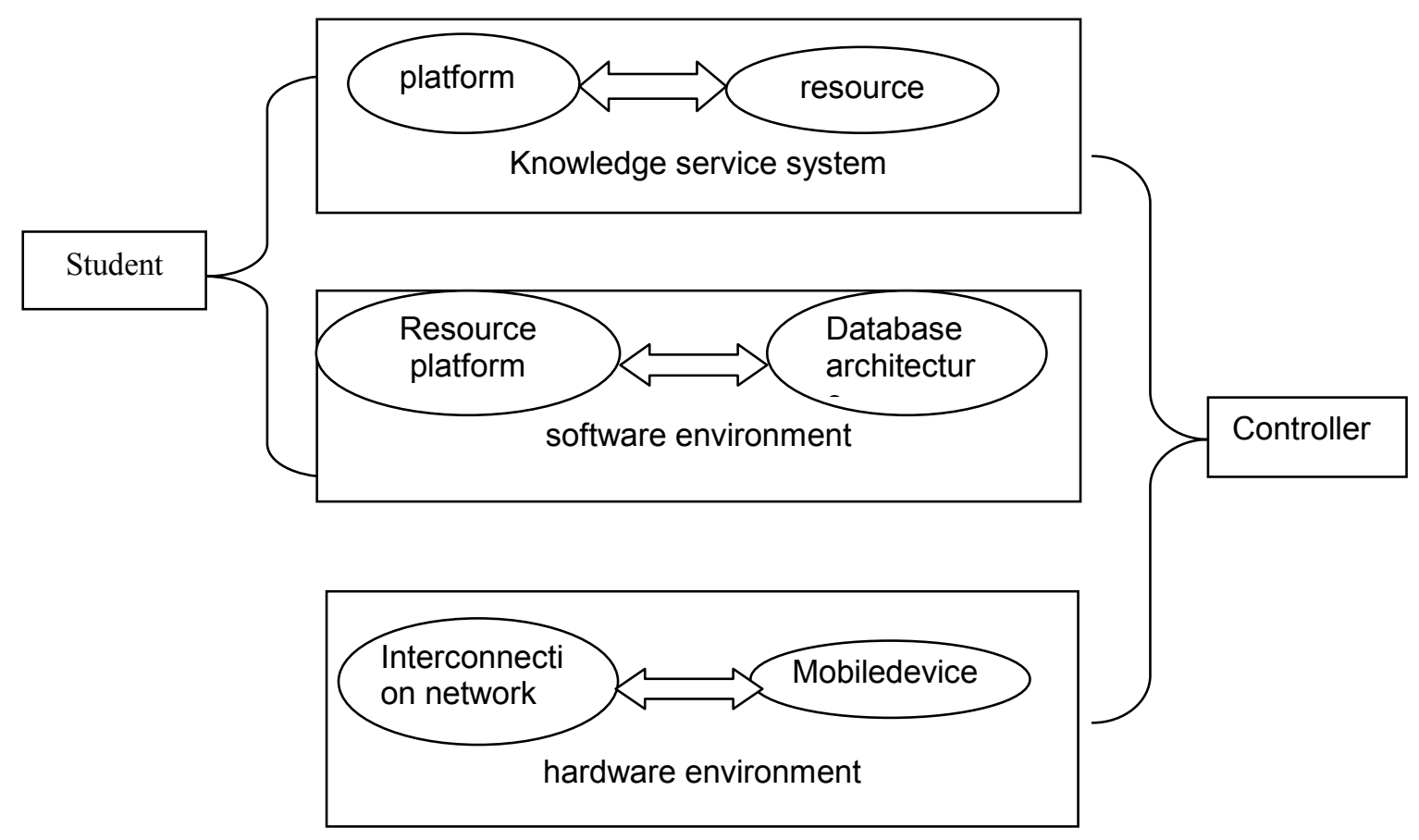

Figure 1. System hierarchy diagram 
Let the students take the initiative to apply for student innovation project.Students conducted independent research studies. Results of the study in three years are students can work independently manipulate scientific research projects and they can be able to write research papers. It achieved some success.

The scientific case is introduced into teaching.It can make students have a general idea of research topics. The students formed a team of 3-5 people conducted a business plan,feasibility analysis,module design,coding design,system testing,product releases and document finishing ${ }^{[7]}$.

Establishment of a Diversified Training Base. Since 2005, the school's training base has been well improved. Training base outside also began to expand. It is with businesses together to create a good reputation. It is a comprehensive training base outside with improving personnel training,teacher quality industry,social services integrated in one. In the past three years we have established a good training school training cooperation project with AMB Dalian,Beijing Danet and Chinese software training base. Nearly a hundred students participated in the project. Students got a good evaluation from their employers.

For 2009, 2010, 2011, students conducted surveys of students in training in the last three years the employment rate is very high,as shown in the following figure. (refer with: Fig. 2) .

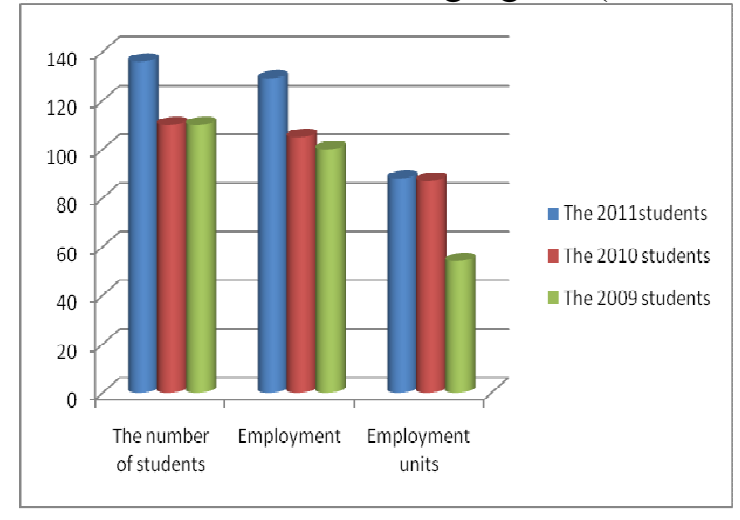

Figure 2. Three student employment

Establish a Scientific and Rational Solution for "Teachers' Training". With the acceleration of computer knowledge updated, new teaching methods need to be applied. Therefore it is necessary to carry out a large number of teaching and research and reform. There must be a team of teachers with reasonable disciplinary structure. Teacher training is mainly used a "regular knowledge sharing" training measures-- Achieve full knowledge sharing between new and old teachers. Practice has proved that such measures can play a "subtle" effect. It greatly improved the level of teaching young teachers in Curriculum Unit. So in teaching contest some people won many College-level awards. Young teachers are encouraged to carry out teaching and research and cultured in the way of education reform. For this purpose, and the reform of curriculum and research management practices are established. Practice has proved that it is very effective to make the practice of young teachers in education reform measures and increase their abilities in training. It even became the main source of the course construction and innovation.

Reform of Examination Method and Examination Form. Increase the proportion of the practice in Reform examination form, intended to refrain from learning by rote, buqiushenjie, focusing on the assessment of the ability to analyze and solve problems. Therefore removed the multiple-choice, blanks, increasing share of essay questions, comprehensive design questions. In the course of teaching,focusing on regular appraisals,assessment is mainly based on what they have learned,how well your students understand and grasp the basic theory,and relevant analysis and resolution capacities within the area; practice test dominated by field tests, operations and comprehensive experiments. Each experiment is to test the students,field testing and evaluation and based on content needs,phased increases comprehensive experiments, to improve students ' practical ability and comprehensive ability to analyze and solve problems. And in an experiment to 
progressively increase the design experiment to cultivate students ' ability to solve problems independently, so that they have a certain capacity for sustainable development. Integrated project appraisal is requiring students to use what they have learned, and complete a comprehensive project and submit project results through an evaluation of the program and make a live defense, examination.

\section{Conclusion}

This study has laid a theoretical foundation for the training of agricultural colleges applied talents. It thus further promotes the idea of changing the concept of higher education in agriculture to adapt to changes in Chinese higher education from elite education to mass education. Meanwhile a series of suitable agricultural colleges applied talents training mode is summed up. This provides some useful experience for the training of agriculture and related fields of application-oriented talents. This study has value for application and promotion in some related art. It thus further enhances the relevance and usefulness of personnel training in higher education. This has important guiding role in improving the quality of teaching and to promote the comprehensive development of the human dimension.

\section{Acknowledgment}

The authors thank the Scientific Research Fund of JiLin Province (GJX2015D250) for support.

\section{References}

[1] Jianqiang Du,Qing Ye,Quan Wen, Keyun Xiong. The Research of Introducing Project Practice Training Mode for Computer Professional Talent [J]. Procedia Engineering, , China 2011,15.

[2] Fuchuan Jiang, Qiang Zheng, Wenwen Shi. The Applied Research of Fuzzy Comprehensive Evaluation on Talent Training Mode of Safety Engineering [J]. Procedia Engineering, , China 2012,43 .

[3] Sun Caiyun. Research on Training Mode of High-Level Innovative Talents in Computer Science in Colleges[J]. Procedia Engineering, , China 2012,29.

[4] Yiyang Fan, Yuting Qiu, Xing Zhang. TRIZ: The Enlightenment of the Training Mode of Excellent Chinese Engineers[J]. Engineering, China 2012,0412.

[5] Yingli XI. Practical Exploration of English Talents' Training Mode of Higher Vocational Education Based on Future Career Abilities[J]. Canadian Social Science, , China 2011,74.

[6] Erlenawati Sawir. Internationalisation of higher education curriculum: the contribution of international students[J]. Globalisation, Societies and Education,2013,113.

[7] Mircea Adrian Marica. On the Ethical Management of the Teaching Profession [J]. Procedia Social and Behavioral Sciences, 2013, 76. 